\title{
A perspectiva descolonial e a (re)leitura dos conceitos geográficos no ensino de geografia
}

\author{
The decolonial perspective and (re)reading of the geographical concepts \\ in geography teaching
}

\author{
Rodrigo Capelle Suess', Alcinéia de Souza Silva"
}

\section{RESUMO}

O modo de colonização da América deixou marcas que refletem nas estruturas econômica, de poder e nos modos de ser, saber e pensar, sobretudo dos países latino-americanos. No Brasil, a imposição eurocêntrica na produção de conhecimentos reflete até hoje na educação, de modo geral, e na Geografia Escolar, de modo específico, pois ainda se encontram permeadas pelo colonialismo do saber. Partindo desse contexto e na busca de uma descolonização da Geografia enquanto disciplina escolar, o objetivo desse artigo é analisar como a perspectiva decolonial pode contribuir para uma educação crítica e humanista em Geografia, especialmente por meio da (re)leitura dos conceitos geográficos. Construído a partir de pesquisa bibliográfica, esses conceitos foram (re)elaborados a partir de temáticas decoloniais como o papel da América no sistema-mundo, o eurocentrismo, a ideia de raça associada a um projeto de dominação, a constituição do Estado-nação moderno, a crítica ao desenvolvimento e ao modelo civilizatório, a colonialidade do poder, colonialidade do ser, colonialidade do saber, e a interculturalidade e a transculturalidade como ferramentas críticas e de transformação. Tal (re)leitura se configura como via de descolonização da Geografia Escolar e de construção de um novo modelo civilizatório que considere diversos saberes, diversas vozes, identidades, maneiras de ser, e novas formas de se constituir e organizar a sociedade.

Palavras-chave: Conceitos; Descolonização; Geografia Escolar

\section{ABSTRACT}

The colonization of America has left marks that reflect economic structures, power structures and ways of being, knowing and thinking, specially in Latin America. In general, the Eurocentric imposition on knowledge production reflects currently on Brazilian education and in School Geography specifically, because they are still permeated by the colonialism of knowledge. Starting from this context and in search of a decolonization of Geography as a school subject, the purpose of this paper is to analyze how the decolonial perspective can contribute to a critical and humanistic education in Geography, particularly by (re-) reading the geographical concepts. Built on bibliographic research, these concepts were (re) elaborated from decolonial themes such as America's role in the world system, eurocentrism, the idea of race associated with a project of domination, the constitution of the modern nation-state, the critique of development and the civilizing model, the coloniality of power, the coloniality of being, the coloniality of knowledge, the interculturality and the transculturality as critical and transformative tools. Such rereading is configured as a way of decolonization of School Geography and the construction of a new civilizing model, which considers diverse knowledge, diverse voices, identities, ways of being, and new ways of constituting and organizing society.

Keywords: Concepts; Decolonization; School Geography 


\section{PALAVRAS INICIAIS}

O reflexo do processo de colonização da América, especialmente da América Latina, ainda é marcante nas estruturas de poder e nos modos de ser e saber dos países desse continente. A concentração de terra, as desigualdades sociais, o novo coronelismo, o racismo, o machismo, o patriarcalismo, a imposição de ideias neoliberais e o lugar que essas nações ocuparam e ainda ocupam no sistema-mundo atual, são provas que permanecem fortes a materialidade e a subjetividade construídas pelo eurocentrismo no período colonial. Com velhas ou novas roupagens essas construções estão longe de romper com a essência eurocêntrica.

Historicamente, desde que o Brasil iniciou seu processo de colonização, sua constituição deu-se sob as bases do colonialismo, do patriarcado e do escravismo, sendo visto por seus colonizadores como uma terra exótica e tropical, ocupada por povos incultos e não dignos de um mesmo tratamento dos europeus. Posteriormente, passou a ser um consulado, formado por povos "sublusitanos, mestiçados de sangues afros e índios" (RIBEIRO, 1995, p. 447), que se encontravam como proletários marginalizados e comandados pelos portugueses. Os anseios dessas populações não eram levados em conta. O real interesse, naquele momento, era impulsionar o poderio marítimo europeu e garantir o enriquecimento da metrópole que explorava essa colônia - Lisboa.

Não satisfeitos com a exploração dos povos nativos que aqui viviam, devido à grande distância cultural e a dificuldade em adaptar a intensa exploração do trabalho, os negros africanos surgiram como uma opção e, por aqui, sua mão de obra foi saqueada por quase quatrocentos anos. Sem uma preocupação mínima com a dignidade e humanidade dessas populações, direitos básicos como alimentação, saúde, educação e moradia foram negados. Nem os ideais republicanos foram capazes de garantir uma dignidade mínima a esses povos. A eles não foram dadas, sequer, a oportunidade de participar do projeto de construção de uma nação (RIBEIRO, 1995; MOREIRA, 2014a). 
Nesse sentido, desde a colonização, o direito e o poder foram pautados em uma legalidade racista e discriminatória. Houve, portanto, uma contínua reprodução da segregação presente na história da formação social e política do Brasil. Contraditoriamente, o discurso da democracia racial passou a fazer parte da cultura brasileira e a sociedade o incorporou no senso comum, sendo um dos responsáveis pelo não reconhecimento da essencialidade dos valores negros, mestiços e indígenas (ANJOS, 2010; MARCHERI e ÁLVARES, 2015).

Além de negros e indígenas, outros grupos sociais, historicamente renegados e até criminalizados, como abastados, mulheres, lésbicas, gays, bissexuais, travestis, transexuais, camponeses sem terra, quilombolas, ciganos e comunidades tradicionais, foram engrossando as parcelas dos excluídos no país e sendo desprezados nos processos de construção da nação. Nota-se que o processo de reconhecimento cultural e de autoidentificação desses grupos tem sido fundamental para a luta contra as imposições sofridas por esses coletivos (MOREIRA e CANDAU, 2007).

Assim, em seu percurso constitutivo, o Brasil enfrentou grandes transformações demográficas, econômicas e sociais que refletiram na estrutura e no funcionamento da sociedade e de suas instituições sociais. O processo de industrialização e o crescimento da economia, a partir da década de 1950, influenciaram na redefinição dos papéis da mulher, possibilitando sua maior inserção no mercado de trabalho. Contudo, não se deve esquecer que ainda existe uma forte imposição cultural, econômica e de produção de conhecimento por parte do centro do sistema-mundo que atribui a países como o Brasil o simples papel de fornecer matérias-primas e que, nesse processo, educação não é prioridade.

Mesmo com a democratização do acesso ao ensino, especialmente a partir da Constituição de 1988 e da Lei n. ${ }^{\circ}$ 9.394/96, a educação no Brasil sempre foi diferenciada entre os segmentos sociais, pois, para a classe dominante a escola é considerada um meio de formação intelectual e acadêmica, já, para as camadas pobres a escola é vista como um meio de qualificação para o trabalho e de mobilidade social (LIBÂNEO, 2012). Associado a essa divisão socioeconômica clássica, temos outras que se associam e que sofrem as piores imposições culturais e políticas, quais sejam: mulheres, negros, povos 
indígenas, população LGBTQ+, camponeses sem terra, comunidades tradicionais, deficientes, pessoas em situação de rua, entre outros grupos sociais considerados minorias políticas.

Esse breve contexto acerca da realidade brasileira, compartilhado em diversos pontos com os povos latino-americanos, demanda um posicionamento crítico da educação. Sabemos que a sociedade não muda só por meio dela, mas sabemos que sem ela nenhuma grande transformação é possível (FREIRE, 1996). Trata-se de resgatar a função crítica da escola, de colocar essa instituição a serviço da transformação social. Para isso, acreditamos que a perspectiva decolonial, ao lado de uma orientação crítica e humanista, pode contribuir muito para esse projeto de sociedade que perpassa a educação. Assumir essa responsabilidade é um trabalho político, assim como todo ato pedagógico, pois o educador é, por si mesmo, um político, uma vez que assume a responsabilidade de decidir, delimitar, executar, acordar ou discordar diante de um contexto no qual as possibilidades não são ilimitadas (FREIRE, 2013, 2014).

A perspectiva decolonial se constitui em um importante movimento de renovação epistemológica para a renovação crítica e utópica das ciências sociais na América Latina no século XXI. A mesma vem sendo fortalecida a partir do final da década de 1990 com a formação do Grupo Modernidade/Colonialidade (M/C), formado por diversos intelectuais latino-americanos situados em diversas universidades das Américas (BALLESTRIN, 2013). Entre suas principais associações e questionamentos podemos destacar: a crítica às concepções dominantes de modernidade; as situações de opressões vivenciadas na América como consequências do colonialismo; o conceito de raça como importante instrumento de dominação europeia; a superação da colonialidade do poder, colonialidade do ser e colonialidade do saber; a ruptura com o eurocentrismo; a busca de uma nova civilidade e novas formas de organização espacial; e ainda, a interculturalidade crítica e a transculturalidade como importantes ferramentas para um novo projeto de sociedade.

A Geografia está no bojo das principais disciplinas escolares e, assim como outras ciências humanas e sociais ensinadas na escola, tem grande responsabilidade em formar integralmente o ser humano, em estar a serviço da radicalidade dos fatos, em 
desmitificar preconceitos e contribuir para a quebra da colonialidade que marcam a estrutura do poder, o modo de ser e o modo de saber desses sujeitos. Outra importante função da Geografia na escola é estudar e permitir que os alunos compreendam que essas questões possuem uma espacialidade, se localizam, possuem uma materialidade, uma intersubjetividade, e implicam ações e reações na sociedade e na natureza. Contudo, para que essa ciência cumpra efetivamente esse papel na educação não são pequenos os desafios a serem superados. Nota-se que, tal como em outros conhecimentos científicos, ainda é forte a marca do eurocentrismo em suas bases constitutivas e no modo de agir-pensar de muitos autores.

Desse modo, esse trabalho tem como objetivo analisar como a perspectiva decolonial pode contribuir para uma educação crítica e humanista em Geografia, especialmente por meio da (re)leitura dos conceitos geográficos. Construído a partir de pesquisa bibliográfica na área das ciências sociais, especialmente Educação e Geografia, o artigo é fruto de uma proposição realizada na disciplina "Perspectivas decoloniais e interculturais em Educação", cursada na Faculdade de Educação da Universidade de Brasília.

\section{COMO DESCOLONIZAR A GEOGRAFIA ESCOLAR?}

Essa pergunta não se constitui em uma questão de fácil resposta ou de apenas uma. Trata-se de um conjunto de possibilidades e contextos que devem ser analisados minuciosamente. O que queremos com esse questionamento é provocar novas reflexões e não pretendemos neste artigo elaborar reflexões únicas e acabadas ou ainda verdades absolutas, mas um processo de indagação que permita dar continuidade a essa importante reflexão. Vemos que um dos passos importantes para adentrar especificamente ao assunto se trata, primeiramente, em identificar quais são as principais concepções teóricas do movimento decolonial e descrever, brevemente, a realidade do ensino de Geografia na educação brasileira, para assim, realizarmos algumas proposições para o difícil trabalho de descolonização da Geografia Escolar brasileira. 


\subsection{Principais concepções teóricas da decolonialidade}

O que apresentaremos é apenas um recorte de algumas das principais discussões teóricas do movimento decolonial, que podem contribuir para a Geografia e o seu ensino na Educação Básica. Dessa maneira, algumas temáticas serão exploradas, dentre elas: a decolonialidade e modernidade; o posicionamento da América no sistemamundo; eurocentrismo; a ideia de raça; o colonialismo do poder, colonialismo do ser e colonialismo do saber; a constituição do Estado-nação moderno; o desenvolvimento e o novo marco civilizatório e a interculturalidade e transculturalidade crítica como ferramentas de transformação da realidade. A partir desses elementos teóricos buscamos realizar alguns questionamentos envolvendo o ensino de Geografia, sem necessidade prévia de respostas, mas como indicadores que podem permitir novas investigações.

O pensamento decolonial é um pensamento que se desprende de uma lógica de um único mundo possível (lógica da modernidade capitalista) e se abre para uma pluralidade de vozes e caminhos. Trata-se de uma busca pelo direito à diferença e a uma abertura para um pensamento-outro. Ele se constitui em uma das variadas oposições planetárias do pensamento único (MIGNOLO, 2007). Trata-se também de questionar outras bases científicas, sobretudo a difundida neutralidade:

A busca de alternativas à conformação profundamente excludente e desigual do mundo moderno exige um esforço de desconstrução do caráter universal e natural da sociedade capitalista-liberal. Isso requer o questionamento das pretensões de objetividade e neutralidade dos principais instrumentos de naturalização e legitimação dessa ordem social: o conjunto de saberes que conhecemos globalmente como ciências sociais (LANDER, 2005, p. 8).

O movimento faz uma intensa crítica à modernidade e à racionalidade, que foram imaginadas, até então, como experiências e produtos, exclusivamente europeus. Não se trata de rompimento, mas de reivindicar que a modernidade também é, e pode ser, fruto de todas as culturas, não apenas europeia ou ocidental. Além disso, reivindica que as ideias de novidade, avanço racional-científico, laico e secular também podem ser apropriadas por outros movimentos, outros sujeitos, outros espaços. A ressignificação 
da modernidade é uma questão central para a libertação humana como interesse histórico da sociedade.

Assim, o que o movimento decolonial busca é outra modernidade, chamada por Dussel (1995) de transmodernidade. Segundo essa proposta a constituição do ego individual diferenciado é a novidade que ocorre com a América e é a marca da modernidade, mas tem lugar não só na Europa, mas em todo o mundo que se configura a partir da América. Reconhece-se que ela representa a mudança do mundo como tal, e que o elemento básico da nova subjetividade se constitui em uma nova percepção do tempo e do espaço que permita a percepção da mudança histórica, isto é, a história como algo que pode ser produzido pelas ações das pessoas.

Igualmente, há a ideia do pensamento fronteiriço (MIGNOLO, 2003) que resiste a cinco ideologias da modernidade: o cristianismo, o liberalismo, o marxismo, o conservadorismo e o colonialismo. Não trata-se de ignorar todo avanço teórico, especialmente o das contribuições históricas e sociológicas do marxismo, mas de uma consolidação de um campo do saber que vai além de Marx. A pretensão é que as ideias do marxismo sejam o mínimo para a reconstrução do saber científico e que ao lado dela outras se juntem.

Relacionando as questões abordadas com a educação, de modo geral, e com a Geografia Escolar, de modo particular, cabe refletirmos sobre as seguintes questões: o conteúdo de Geografia valoriza a pluralidade de vozes e caminhos em sua produção? Em sala de aula, eu, enquanto professor, recorro a diversidade de vozes para o processo de construção do conhecimento escolar? Quando sigo a ideia de neutralidade científica no ensino de Geografia, estou me comprometendo com qual projeto de educação e de sociedade? A quem serve um ensino neutro de Geografia? Em minhas falas costumo direcionar os avanços da sociedade apenas aos países do Norte? Qual é o espaço que abro em minhas aulas para destacar a produção de outros povos na constituição da modernidade? Busco conhecer outras perspectivas filosóficas que possibilitam uma nova leitura do espaço geográfico, considerando a pluralidade e complexidade atual?

Quijano (2005) faz um resgate da importância da América, especialmente da América Latina, na constituição do atual sistema-mundo. Assim, destaca que a 
globalização vigente inicia-se com a exploração da América no século XVI, o que levou esse continente a se constituir na primeira "id-entidade" da modernidade, antes mesmo da Europa. A ideia de raça, em seu sentido moderno, não tem história antes da América. Sua aplicação levou a produção, nesse continente, de identidades sociais historicamente novas, como o índio, o negro e o mestiço, na medida em que as relações sociais que estavam se configurando eram relações de dominação. O que surge, a partir daí, é um sistema hierárquico de lugares e papéis sociais, no qual o europeu se naturalizou como raça superior, ao se denominar "branco".

Como resultado desse processo temos a constituição da Europa como nova identidade, posterior e relacionada à dominação da América, e à expansão do colonialismo europeu ao resto do mundo. Isso favoreceu a elaboração da perspectiva eurocêntrica do conhecimento e com ela a elaboração da noção de raça como naturalização dessas relações coloniais de poder entre europeus e não-europeus. Trata-se de reconhecer a privilegiada posição global que a Europa ganhou com o controle da América e de suas fartas riquezas naturais e minerais. Essa vantagem impulsionou os europeus ao controle do comércio mundial, ultrapassando, inclusive, as potências orientais. Contudo, deve-se especificar que não se trata da Europa em sua totalidade, mas dos países conhecidos como Europa ocidental, sede do controle do mercado mundial. Assim, pode-se dizer que a partir da América um novo espaço/tempo se constitui, material e subjetivamente falando.

Não são poucas as indagações a serem realizadas por nós professores de Geografia a respeito de um novo olhar sobre os continentes americano e europeu: como a América se apresenta em nosso currículo? Qual é a mensagem principal que os nossos livros didáticos transmitem desse continente? O que espero que os meus estudantes aprendam sobre a América? Levo em conta todo o processo de opressão para explicar a conjuntura atual desse continente ou trato com naturalidade tal situação? Resgato o papel da América quando trabalho Globalização e Comércio Mundial? Qual é o papel que a América, especialmente a América Latina, possui em minhas aulas? Questiono como constituiu a riqueza dos países europeus, ou trato esse 
processo com naturalidade? Insiro a colonização da América quando vou falar da atual situação do continente europeu?

Como previamente apresentado, a ideia de raça se constituiu em um processo crucial para o efetivo domínio europeu sobre terras além de seu território, se tornando um importante elemento de dominação. Trata-se de uma classificação social que viabiliza a construção da noção de superioridade e da pureza sanguínea da raça branca que justificava sua ação como uma espécie de mal necessário para desenvolver povos naturalmente inferiores, uma transferência cultural que beneficiaria todos os povos (BALLESTRIN, 2013).

Assim, a partir do domínio da América houve uma classificação social da população mundial de acordo com a ideia de raça. Trata-se de uma construção mental que expressa a experiência básica da dominação colonial e que, a partir daí, perpassa as dimensões mais importantes do poder mundial. Tal concepção serviu para naturalizar o processo de dominação baseada em um pressuposto de relação superioridade/inferioridade entre dominantes e dominados (QUIJANO, 2005).

O capitalismo logo se apropriou dessa noção para impor uma sistemática divisão racial do trabalho: índios - servidão; negros - escravidão; europeus - assalariados, donos de meios de produção e classe dirigente. Desenvolveu-se, assim, a percepção de que o trabalho pago era privilégio dos brancos, pois os novos colonizados eram raças inferiores, portanto, inferiores/ínferos aos europeus (QUIJANO, 2005). Posteriormente, o que notamos é uma transformação dos menos privilegiados em assalariados, mas sem perder alguns traços e papéis legados pelo colonialismo. São novas formas em velhos tonéis.

Associado com a ideia de gênero e trabalho formam-se as linhas principais de classificação que consolidaram o capitalismo mundial/moderno no século XVI (QUIJANO, 2005). Nessas circunstâncias, o modelo a ser seguido foi o homem heterossexual, branco, patriarcal, cristão, militar e capitalista europeu (GROSFOGUEL, 2008).

Novamente são necessárias algumas indagações sobre as principais linhas de pensamento apresentadas: como o racismo e outras formas de preconceitos estão 
impregnadas em nosso currículo oficial, na nossa prática docente e no currículo oculto que ronda as nossas salas de aula? Como a Geografia Escolar contribuiu historicamente para materializar o racismo na educação e como ela pode contribuir atualmente com a desconstrução dessa ideia? De que forma essas teorias podem nos ajudar a construir um novo ensino de Geografia? Costumo levar em conta o papel do conceito de raça no processo de colonização da América e na Geografia contemporânea da América? Como a desconstrução dessa ideia pode humanizar o ensino de Geografia e o papel da educação escolar?

As relações intersubjetivas e culturais entre a Europa e o restante do mundo se deram a partir de novas categorias: oriente - ocidente, primitivo - civilizado, mágico/mítico - científico, irracional - racional, tradicional - moderno. Trata-se de uma perspectiva binária ou dualista de conhecimento, peculiar ao eurocentrismo. 0 eurocentrismo não abarca todos os modos de conhecer de todos os europeus, em todas as épocas, mas abarca uma específica racionalidade ou perspectiva de conhecimento, qual seja, a dos países da Europa ocidental. Essa produção tenta tornar-se mundialmente hegemônica, colonizando e sobrepondo-se a todas as outras (QUIJANO, 2005).

Assim, esse autor elenca alguns elementos mais importantes do eurocentrismo, tais como uma articulação peculiar entre um dualismo (pré-capital - capital, não europeu - europeu, primitivo - civilizado, tradicional - moderno, etc.) e um evolucionismo linear unidirecional de algum estágio de natureza à sociedade moderna europeia; e a naturalização das diferenças culturais por meio da ideia de raça e um estereótipo de que tudo que não é europeu é percebido como passado. São processos que só poderiam ser desenvolvidos associados à colonialidade de poder, instalada primeiramente na América.

Em uma fase mais recente, marcada pela globalização capitalista e pela cartilha neoliberal, Coronil (2005) acredita em uma metamorfose do eurocentrismo, chamada por ele de "globocentrismo", que associado ao "ocidentalismo" geram concepções de mundo que dividem os componentes do mundo em unidades isoladas, desagregam suas histórias de relações, transformam a diferença em hierarquia, naturalizam essas 
representações e reproduzem as atuais relações assimétricas de poder (CORONIL, 2005).

Por meio disso, indagamos: como a dualidade se encontra presente em nosso currículo? Como ela interfere no ensino de Geografia? Quais são as principais dualidades da Geografia que impactam no ensino voltado a uma formação integral e intercultural? Para simplificar o processo de compreensão do aluno, costumo ensinar apenas um caminho ou uma solução para determinado problema? Esse(s) caminho(s) segue $(m)$ qual orientação? A qual projeto de sociedade ele(s) contribui(em)? Tenho uma visão eurocêntrica de ensino de Geografia e de visão de mundo? Como posso me questionar e questionar os meus estudantes a respeito dessas subjetividades? Como busco relacionar a globalização com o processo de expansão do pensamento eurocêntrico? Outros caminhos são possíveis? Quais são eles?

Um dos eixos básicos do pensamento decolonial se constitui em investigar a colonialidade do poder, a colonialidade do ser e a colonialidade do saber, pois as relações de colonialidade nas esferas econômica e política não findaram com a destruição do colonialismo. O conceito de colonialidade do poder possui duas pretensões: primeiro, denunciar a continuidade das formas coloniais de dominação após a independência desses países; segundo, por sua capacidade explicativa que contemporaniza, nos trazer à memória processos históricos intencionalmente apagados ou deformados pelo discurso da modernidade. Sendo assim, também é um conceito que tem espaço no campo dos movimentos sociais que o associam a um elemento teórico de luta (BALLESTRIN, 2013).

O poder vem da interferência cultural e econômica das antigas metrópoles, fortalecidas por meio das estruturas atuais do sistema-mundo capitalista, que têm como grandes representantes os organismos multilaterais, como a Organização das Nações Unidas (ONU), o Banco Mundial (BM) e o Fundo Monetário Internacional (FMI), além das empresas multinacionais e do alto grau de dependência tecnológica e financeira. A globalização capitalista permite, dessa maneira, que as economias estejam cada vez mais interligadas e no caso específico dos países latino-americanos trata-se de uma subordinação econômica. Mesmo os maiores produtores de commodities do 
mundo estando nessa realidade geográfica, não são eles que definem o seu preço no mercado internacional. A paridade do dólar agrava a economia de diversas nações latino-americanas que veem os seus produtos e suas moedas desvalorizarem, ao passo que suas dívidas, agora medidas por esse parâmetro, dobram de tempo em tempo.

Deve-se lembrar que as populações colonizadas tiveram seus descobrimentos e patrimônios mais aptos ao desenvolvimento capitalista expropriados. Os colonizadores reprimiram, da maneira que podiam, as formas de produção de conhecimentos, produção de sentidos, o universo simbólico, a subjetividade e outras manifestações dos colonizados. Essa postura marca uma América, que por muito tempo foi condenada a ser uma subcultura camponesa, iletrada, sem herança intelectual objetivada (QUIJANO, 2005).

A colonialidade do poder implica em um contexto histórico mundial em que todos os países têm um fator em comum: lidar com a invasão, diplomática ou bélica, beneficiosa ou desastrosa, da Europa ocidental e dos Estados Unidos. Por vez, a Europa ocidental e os Estados Unidos têm algo em comum: uma história de quinhentos anos de invasão, diplomática ou armada, no resto do mundo (MIGNOLO, 2007). Mignolo (2003) destaca que a colonialidade do poder envolve o controle da economia, da autoridade, da natureza e dos recursos naturais, do gênero e da sexualidade, da subjetividade e do conhecimento.

A colonialidade do ser refere-se a experiência vivida da colonização e seu impacto na linguagem. Ela envolve como o ser se reconhece, qual é a sua auto-imagem. Trabalhar com essa noção implica a ruptura com a ideia de diferenciação natural entre os sujeitos, com a rejeição da ideia de raça, além da renegação de sentimentos de superioridade e inferioridade (MALDONADO-TORRES, 2007). Dessa forma, como defende Quijano (2005, p. 126), “[...] é tempo de aprendermos a nos libertar do espelho eurocêntrico onde nossa imagem é sempre, necessariamente, distorcida. É tempo, enfim, de deixar de ser o que não somos".

Essas estruturas de poder marcam o modo de produzir e de se apropriar do conhecimento dos ex-povos dominados pelos europeus. Dessa maneira, podemos falar de uma colonialidade do saber associada com a diferença colonial e com a geopolítica 
do conhecimento (MIGNOLO, 2002). Como consequência, temos uma elaboração intelectual marcada pelo eurocentrismo, com visões de mundo, métodos, autores e técnicas produzidas na Europa e difundida em outros locais para serem reproduzidas ou reformuladas dentro da perspectiva imposta.

É comum nas ciências sociais o predomínio de autores europeus, nas quais o universalismo etnocêntrico, o eurocentrismo teórico, o nacionalismo metodológico, o positivismo epistemológico e o neoliberalismo científico se consolidam como elementos normativos do fazer-pensar dessas ciências (BALLESTRIN, 2013). Para Mignolo (2007) todo conhecimento é localizado. Isso nos faz percorrer por dois caminhos, um de crítica ao conhecimento produzido na Europa, que tende a ser vendido e aplicado no globo como deslocalizados e universais, e outro de reivindicação do direito da América produzir esse conhecimento, reconhecendo as características de sua localização histórica e geográfica diante do mundo.

Ainda a respeito da colonialidade do saber, Grosfoguel (2016) identifica quatro genocídios/epistemicídios associados ao racismo/sexismo epistêmico que ocorreram ao longo do século XVI, período no qual a Europa estava no auge da colonização. Trata se, assim, de genocídio/epistemicídio contra muçulmanos e judeus na conquista de AlAndalus, contra os povos nativos na conquista das Américas, contra os africanos na conquista da África e a sucessiva escravização e descolamento dos africanos como escravos para as Américas, e ainda, em desfavor das mulheres europeias queimadas vivas, acusadas de bruxaria.

Considerando esses importantes eixos, muitas questões podem ser levantadas e associadas ao ensino de Geografia, quais sejam: como a colonialidade do poder, a colonialidade do ser e a colonialidade do saber podem contribuir para a ressignificação do ensino de Geografia e da minha prática, enquanto docente? Quais são os efeitos, por outro lado, de não levar em conta essas questões no ensino de diversos conteúdos geográficos e no modo de pensar-agir em Geografia em sala de aula? Posso me apropriar dessas questões como instrumentos de transformação social por meio da educação? Quais são suas contribuições para o ensino da Geografia brasileira e da Geografia do Brasil em sala de aula? Como elas podem representar uma ferramenta de 
releitura do espaço mundial no ensino? De que forma esses conceitos podem contribuir para um resgate cultural significativo das culturas dos meus estudantes, especialmente das mulheres, dos negros, da população LGBTQ+, dos deficientes e dos camponeses que convivem na escola e nos arredores dela?

Uma questão bastante importante resgatada pela decolonialidade é a constituição do Estado-nação moderno/capitalista como um êxito para manutenção do sistema-mundo e da dominação da elite sobre as minorias políticas. O Estado-nação se constitui em uma estrutura de poder. Estrutura essa que não representa todos os grupos, mas, geralmente, um grupo, o dominante. Para sua consolidação é preciso ter ou forjar algo em comum, algo para compartilhar e corresponder a memória coletiva nacional. O processo de constituição envolve uma centralização do poder sobre um território e sua população em um dado espaço/tempo. O poder político deve se mostrar forte e estável. Quando não é possível a homogeneização devido a diferença sociocultural muitos grupos são expulsos ou exterminados. Nem sempre a existência de Estado central forte é satisfatória para produzir relativa homogeneização de uma população previamente diversa e heterogênea. A França, por exemplo, por meio da democratização radical das relações sociais e políticas contribuiu de forma significativa para um "afrancesamento" efetivo, ainda que não totalitário, dos povos que habitavam o território do país. Destaca-se, com isso, que um importante processo de democratização da sociedade é a condição básica para a nacionalização dessa sociedade e de sua organização política num Estado-nação moderno (QUIJANO, 2005).

Nos Estados Unidos, os índios foram excluídos dessa nova sociedade. Foram considerados estrangeiros, mesmo sendo donos das propriedades de terras saqueadas no decorrer da expansão do território estadunidense. A constituição desse Estadonação, nesse viés de exclusão dos povos autóctones, foi genuinamente representativa da maioria da população. A distribuição democrática de recursos, como é o caso da divisão de terras, também contribuiu para a construção de uma identidade em comum. Em um primeiro momento a situação nos países do chamado Cone Sul da América Latina (Argentina, Chile e Uruguai) foi similar à ocorrida nos Estados Unidos. Nesses 
três países sul-americanos a população negra foi uma minoria durante o período colonial, em comparação com outras regiões dominadas por espanhóis ou portugueses. A homogeneização em tais países favoreceu a extrema concentração de propriedade da terra e tornou impossível qualquer tipo de relações sociais democráticas entre os próprios brancos e em consequência de toda relação política democrática. Assim, o que podemos falar como marcante na consolidação e sobrevivência do Estado-nação na América é que a homogeneização de seus membros se deu, em boa parte, pela eliminação massiva de alguns deles (índios, negros e mestiços), e não por meio de uma democratização fundamental das relações sociais e políticas (QUIJANO, 2005).

Alguns casos, a exemplo do México e da Bolívia, chegaram mais longe no caminho da descolonização social. No caso brasileiro, os negros e a maioria dos índios não eram vistos como dignos da humanidade em participar das decisões do Estadonação. O processo de independência não rompeu com a colonização por completo, uma vez que começaram a agir sobre o território organismos internacionais e empresas multinacionais. A pequena minoria branca no controle dos Estados independentes e das sociedades coloniais, compostas por índios, negros e mestiços, impossibilitou a construção de um ponto de interesse que levasse a consolidação do Estado-nação. O grau de dependências das ex-colônias ainda é elevado, já que a elite dirigente ainda se vê muito mais próxima dos interesses de seus pares europeus do que da população local (QUIJANO, 2005).

Acreditamos que esse debate é de fundamental importância para a Geografia Escolar. Como perguntas temos as seguintes: costumo considerar essa concepção de Estado-nação no ensino de Geografia? Qual é o impacto de levar em conta essa concepção no ensino da Geografia local, regional e global? Como essa perspectiva de Estado-nação pode contribuir para uma releitura do espaço geográfico? Como essa noção pode contribuir para a reelaboração da história dos povos oprimidos e podem equipá-los de instrumentos para a transformação social? De que forma esse conhecimento pode permitir uma atuação cidadã e intercultural dos alunos? Quais são os caminhos possíveis para transformação do Estado-nação na América Latina em um 
estado plurinacional mais democrático e que represente os interesses de todos os povos que ocupam esse território?

Como dito, a perspectiva decolonial pressupõe uma crítica ao modelo de "desenvolvimento" eurocêntrico, especialmente aquele implementado e mantido após a constituição dos Estados-nação na América Latina. Esse modelo atual, como denuncia Escobar (2014), se reveste em uma imposição cultural, econômica e de produção de conhecimento por parte das metrópoles - países do centro, o norte global. Em seu sentido moderno, o desenvolvimento nasce com a Doutrina Truman em 1949 por meio da cartilha que defende altos níveis de industrialização e urbanização, tecnificação da agricultura, rápido crescimento da produção e do nível de vida e uma educação baseada em princípios "modernos". Atualmente, em sua versão mais atualizada, temos a cartilha do neoliberalismo, elaborada no Consenso de Washington em 1990, que associa os efeitos benéficos do capitalismo aos avanços da tecnologia, meios de comunicações e transportes (ESCOBAR, 2014).

Nesse contexto, após os países ricos realizarem suas reformas educacionais prómercado, tentam viabilizar o mesmo processo em âmbito internacional, porém visam manter a atual divisão social e territorial do trabalho nos países mais pobres. Trata-se de uma medida verticalizada/centralizada, que vem de cima para baixo, exercida pelo poder financeiro e contratual dos organismos multilaterais, dos quais os países do Norte Global são os principais acionistas. Os mais conhecidos são o FMI e o BM. A esse grupo hegemônico interessa um mundo sem fronteiras, pelo menos para os demais países, o que corresponde a uma modernização da economia e das relações de trabalho que pressupõem uma abertura ao capital transnacional, reduzida atuação do Estado na economia e no setor produtivo e diminuição do déficit público e no gasto com políticas públicas sociais. Nesse sentido, as recomendações desses organismos seguem o princípio do mercado como fundador, unificador e autorregulador da nova ordem econômica e política mundial. A educação como parte da sociedade, ou minimamente vista como um gasto do Estado, é intensamente afetada (LIBÂNEO, OLIVEIRA e TOSCHI, 2012). 
De 1951 até os dias de hoje temos, predominantemente, três momentos que marcam a concepção de "desenvolvimento": a teoria liberal que tenta associar modernização ao crescimento econômico, com a defesa de um único caminho possível no qual os países direcionam de sociedades tradicionais para sociedades modernas; a teoria da dependência, de orientação marxista, na qual associa as raízes do subdesenvolvimento entre a conexão da dependência econômica externa e a exploração social interna. Vai contra a explicação liberal que justifica a falta de desenvolvimento a suposta falta de capital, tecnologia e outros valores modernos; e por fim, temos a teoria pós-estruturalista que denuncia o desenvolvimento como um discurso de origem ocidental, que opera como um poderoso mecanismo da produção cultural, social e econômica no Terceiro Mundo (ESCOBAR, 2014).

Essa última teoria abre espaço para a criação do "pós-desenvolvimento" ou pela busca de alternativas "ao" e não somente "de" desenvolvimento. Ela denuncia, ainda, o caráter elitista da produção de conhecimento que exclui diversas vozes e serviu para legitimar o modelo liberal nos países explorados no sistema-mundo. O modelo civilizatório ocidental é invocado como a principal causa de uma atual crise global do clima, da alimentação e da pobreza. Dessa forma, Escobar (2014) defende uma postura crítica ao "desarrollo", elenca as contribuições do Grupo Modernidade/Colonialidade, e destaca a contribuição de ouvir outras vozes para a construção de um novo modelo civilizatório, como é o caso dos povos indígenas e grupos subalternos e os seus conceitos de "Buen Vivir", "o comunal", "pluriverso" e "Direito da Natureza", como pode ser melhor explorado em seu livro (ESCOBAR, 2014).

Entre algumas inovações que Escobar (2014) propõe para a reinvenção do nosso modelo civilizatório, encontra-se o Estado plurinacional, a sociedade intercultural, as inovações multiculturais e multiepistêmicas e o fortalecimento das redes agroecológicas. Tratam-se de alternativas que tendem a ser anticapitalistas, que afirmam a vida em todas as dimensões e exploram múltiplas concepções de nação, natureza, economia, de tempo e de cidadania. Alternativas essas que levam em conta as cosmovisões e práticas de comunidades indígenas, afro e campesinas, das mulheres e do movimento LGBTQ+ como possibilidades de contribuir com as bases de um 
modelo civilizatório alternativo. Essa nova civilidade parte da despatriarcalização da sociedade e das relações com a natureza como parte da descolonização, libertação e igualdade. Além disso, reconhece o direito dos povos em debater e decidir a respeito de sua identidade, território, soberania alimentar, justiça ambiental, paz, autonomia, bem viver, qualidade de vida, etc. Uma ideia forte que ajuda na busca desse novo projeto de sociedade é a de sustentabilidade, mas não como qualquer concepção, mas como uma versão forte, descolonizadora, libertadora no econômico, no cultural e no social, e que, como resultado final, viabilize alternativas ao desenvolvimento (ESCOBAR, 2014).

Esse debate teórico nos leva a diversos questionamentos inerentes às nossas práticas enquanto professores de Geografia na Educação Básica: no ensino de Geografia temos questionado o nosso modelo de desenvolvimento e o modelo de desenvolvimento global? Até que ponto naturalizamos o desenvolvimento enquanto único caminho possível para a felicidade dos povos ao ensinar Geografia? No ensino estamos seguindo uma perspectiva crítica de desenvolvimento ou estamos rezando a cartilha liberal de desenvolvimento? Qual é o impacto dessa perspectiva na formação dos nossos estudantes? Como um posicionamento mais crítico poderia contribuir para uma nova leitura do espaço geográfico e uma significativa mudança de visão de mundo dos estudantes? É possível pensar em um novo modelo civilizatório, sobretudo com a contribuição de diversos grupos sociais historicamente excluídos desse processo? Qual é a importância de identificar e refletir sobre os modelos alternativos de/ao desenvolvimento no ensino de Geografia?

Todos esses apontamentos apresentados pelo movimento decolonial são instrumentos teóricos que visam a transformação da realidade vigente em uma realidade que considere as diversas vozes, identidades, maneiras de ser, novas formas de se constituir e organizar a sociedade, e diversos saberes. Trata-se de uma nova forma de sentir-pensar-fazer o espaço-tempo-sociedade. Assim, deixamos por último a importância de um desenvolvimento de uma interculturalidade e transculturalidade crítica para efetivação desse projeto. Associado a essa questão, debatemos também as proposições de unidade na diversidade e a Pedagogia da Tolerância defendida por 
Freire (2013), pois acreditamos que muitas proposições desse autor se aproximam das concepções do movimento decolonial.

Antes de falarmos de interculturalidade cabe diferenciá-la do multiculturalismo, pois esse último apenas reconhece a diferença e a coexistência de diversas culturas, sem necessariamente resultar em uma inter-relação entre elas. Também pode ser utilizado, como vem sendo pelo sistema capitalista, para reforçar a dominação cultural e a neutralização das culturas, uma vez que se constrói uma falsa ideia de democracia cultural (étnico-racial, de gênero, de classes, etc.). Já, a interculturalidade envolve o sentido relacional (o contato e intercâmbio entre culturas) e um sentido funcional (necessidade de reconhecimento da diversidade e diferença cultural com vista a incluir todos na estrutura social). Entretanto, não limita-se a essas questões, visto que deve estar a serviço da transformação social e a favor da reinvenção do modelo civilizatório, de sociedades diferentes a partir de um câmbio, principalmente dos subalternos para construção de mundo outros (WALSH, 2012).

Nesse sentido, trata-se de uma proposta de sociedade como um projeto político, social, epistêmico e ético, dirigido à transformação estrutural e sócio-histórica. Para tanto, deve-se, então, reconstruir condições de saber, de ser e de poder. A interculturalidade, nesse processo, é caracterizada como um diálogo de iguais, no qual duas culturas fazem trocas e vão além da simples justaposição que define a multiculturalidade (WALSH, 2012). Outro passo importante é considerar a importância da transculturalidade, isto é, uma abertura de todas as culturas a tudo aquilo que a atravessa e a ultrapassa, tendo "a acolhida e valorização da cultura do outro como ponto de início para a construção de uma ordem cultural integradora" (LUCHESI e MALANGA, 2011, p. 83).

O que falta entre nós, oprimidos, é unidade, especificamente a unidade na diversidade:

Unidade na diversidade não significa, de modo algum, que os diferentes diluam suas diferenças em favor de um [...] Unidade na diversidade não é o mesmo que unidade sem diversidade ou unidade para a diversidade. [...] A igualdade de nós e dos objetos pode viabilizar a unidade na diferença. 
Enquanto a falta de unidade entre os diferentes conciliáveis ajuda a hegemonia do diferente antagônico (FREIRE, 2013, p. 110, itálico nosso).

Nesse aspecto, o autor possui uma visão humanista sobre diversidade. A ideia de união entre os diferentes pode representar a ideia de que ser diferente não é ser minoria, mas uma imensa maioria de diferentes que desejam construir uma sociedade mais igualitária. A ideia de unidade na diversidade vai de encontro à perspectiva da modernidade de fragmentação. Nesse aspecto, a unidade visa lutar contra as hegemonias de pensamentos, políticas públicas segregadoras, contra uma sociedade elitizada e das elites, e a favor de uma sociedade da boniteza, da ética, da estética, do respeito e da tolerância.

Quando esse educador defende uma Pedagogia da Tolerância, o mesmo faz questão de reforçar que a tolerância se constitui enquanto qualidade de conviver com o diferente, e não com o inferior. Não trata-se de um valor de gratidão, mas uma qualidade basilar da vida democrática, uma virtude da convivência humana. Assim, nega a ideia que haja, especificamente aquele que tolera ou que é tolerado, todos se toleram e, por isso, se fazem enquanto ser humano, enquanto sociedade. O que buscamos para a sociedade é uma Pedagogia da Tolerância que não negue a humanidade do outro por ele ser diferente de mim. Isso demanda que eu respeite os seus sonhos, seus desejos, suas vontades, suas manifestações. Dessa forma, para o ensino temos que incorporar o princípio da tolerância como um elemento que permite aprender com o diferente (FREIRE, 2013).

Desse modo, fechamos essa seção com questionamentos importantes que podem nos ajudar a descolonizar a Geografia Escolar, quais sejam: como a interculturalidade pode transformar o ensino de Geografia? Como ela pode permitir uma nova abordagem dos conteúdos por parte do professor? Como ela pode contribuir para a formação cidadã e democrática em Geografia? O que a interculturalidade implica para o modo de como o conhecimento geográfico é construído e como ela pode tornar mais significativo o processo de construção de conhecimentos escolares? Como a transculturalidade pode fazer frente à globalização capitalista e se constituir em uma nova alternativa? Trabalhamos um ensino de Geografia que favorece a unidade na 
diversidade? Os professores têm sido tolerantes com a realidade pluralista das escolas? De que maneira, enquanto formadores, podemos contribuir para uma Pedagogia da Tolerância? Como o conhecimento geográfico pode ir ao encontro dessa perspectiva?

\subsection{O ensino de Geografia na educação brasileira}

Quando falamos que é necessário descolonizar a Geografia Escolar partimos de uma realidade concreta que nos evidencia uma educação nacional colonizada e, igualmente, uma ciência geográfica também permeada pelo colonialismo do saber. A Geografia enquanto disciplina escolar não se dá de forma isolada, mas se relaciona, se apropria e demanda novas necessidades do campo acadêmico dessa ciência. Por outro lado, não é apenas o campo acadêmico a única preocupação dessa disciplina escolar, mas também todo o processo formativo desses profissionais e toda ordem que interfere na organização do espaço/tempo escolar e no trabalho pedagógico do professor e do estudante. Sendo assim, a nossa preocupação se constitui em analisar o fortalecimento da ciência geográfica no Brasil, posicionar o ensino dessa ciência relacionada a um contexto maior de precarização da educação e da formação docente, e denunciar o impacto do neoliberalismo na educação, em geral, e na Geografia Escolar, em específico.

Segundo Moreira (2010) a Geografia brasileira faz parte do pensamento geográfico mundial e se alimenta, fortemente, das produções de outros países. Assim, quatro distintas perspectivas dominam a formação do pensamento geográfico brasileiro: a francesa, de Reclus, Vidal, Sorre, Deffontaines e Moinbeg; a francogermânica, de Brunhes; a germânica, de Ratzel, Hetter e Waibel; e a norte-americana, de Sauer e Hartshorne. Mais recentemente, com a amplitude que o horizonte humanista toma no Brasil, podemos acrescentar a influência anglo-saxônica, de autores como YiFu Tuan, Anne Buttimer e Eduard Relph.

O que vemos no Brasil são duas grandes fases, a informal e a formal. A informal se faz presente no pensamento dos viajantes, cronistas e naturalistas, ou seja, trata-se de uma Geografia não acadêmica, não institucionalizada, realizada por pessoas sem 
formação específica (MOREIRA, 2010). Já a segunda pode ser dividida em alguns períodos: 1. 1934-1955 - criação do primeiro curso de Geografia pela Universidade de São Paulo (USP) e logo em seguida pela Universidade do Distrito Federal (UDF), criação da Associação dos Geógrafos Brasileiros (AGB) e do Instituto Brasileiro de Geografia e Estatística (IBGE). Destaque para autores como Deffontaines, Moinbeg e Rullean; 2. 1956-1967 - realização do Congresso Internacional de Geografia da União Geográfica Internacional (UGI) no Rio de Janeiro e reafirmação da influência de europeus e norteamericanos na Geografia brasileira; 3. 1968-1977 - fortalecimento da New Geography - Geografia teorética-quantitativa, fortalecimento do IBGE e da influência dos norteamericanos como Friedmann, Brian Berry, Chistaller, e no cenário brasileiro do geógrafo Speridião Faissol; 4. A partir de 1978, com o Congresso Nacional da Associação dos Geógrafos Brasileiros em Fortaleza, temos o fortalecimento do marxismo na Geografia brasileira, com destaque a autores europeus como Yves Lacoste e Massimo Quaini, e ao brasileiro Milton Santos (CORRÊA, 1994).

Como enleva Moreira (2014b), o que podemos observar a partir desse último período é uma tendência pluralista, um novo holismo antes de um novo paradigma. Assim, a Geografia Teorética-quantitativa, o marxismo, a percepção, o humanismo, a influência das filosofias dos significados, como é o caso da fenomenologia, também têm espaço na produção do conhecimento brasileiro e mundial. O que observamos no percurso da História é a forte influência ocidental no pensar-fazer da Geografia brasileira, inclusive na Geografia Escolar, na qual reproduz o que foi posto de cima para baixo, isto é, da academia para a escola, e da Europa e dos Estados Unidos para o Brasil.

Associado ao contexto de desenvolvimento particular da ciência geográfica temos o contexto da educação brasileira e dos cursos de formação de professores. Nota-se que, nesses 469 anos de história da educação brasileira, que se inicia em 1549 com a vinda dos jesuítas para o Brasil, a educação não tem sido um carro chefe no desenvolvimento da sociedade brasileira. É evidente o significativo avanço que tivemos na universalização da educação após a Constituição de 1988, contudo estamos longe da garantia de uma universalização da qualidade mínima na educação brasileira (SAVIANI, 2008). 
A Geografia penetrou no ensino regular desde meados do século XIX. Desde então, avanços e retrocessos, órgãos oficiais, movimentos sociais e vários pensadores se voltaram a pensá-la em âmbito escolar. Foram consolidados cursos de formação, disciplinas com intuito de formar professores, instituídos concursos públicos e novos currículos. As licenciaturas sofreram alterações, sobretudo com o Golpe Militar. Foram criadas licenciaturas curtas nas escolas superiores. História e Geografia foram unificadas em uma só disciplina, conhecida como Estudos Sociais. Por fim, constata-se que, entre 1960 e 1970 a academia sofreu com as perseguições daqueles que mostrassem contraditório ao governo ou sua ideologia adotada, e só a partir de 1980 houve o processo de redemocratização (PONTUSCHKA, 2013).

Por outro lado, é muito preocupante o avanço do neoliberalismo na nossa legislação, especialmente na educação nacional e na formação de professores. pacote do Banco Mundial que previa a universalização do acesso escolar, financiamento e repasse de recursos financeiros, bem como a descentralização da gestão, com forte caráter neoliberal, influenciou quase todas as políticas públicas pós Constituição de 1988. O Plano Decenal de Educação, os Parâmetros Curriculares Nacionais, o ensino a distância, o Sistema Nacional de Avaliação, as políticas do livro didático e a própria Lei de Diretrizes e Bases da Educação são produtos que bebem dessa perspectiva.

Esse aspecto agrava ainda mais a grande desigualdade nos locais de formação docente no Brasil. Enquanto vemos que a maioria dos professores são formados em cursos presenciais no Centro-sul, as pessoas que residem no Nordeste e Norte acabam sendo formadas em cursos aligeirados e a distância. Entretanto, é válido mencionar que os números de cursos de licenciatura em Geografia são cada vez maiores, sendo ofertados nessa modalidade (a distância) nas áreas com maior possibilidade de encontrar licenciaturas em cursos superiores presenciais públicos e privados (PONTUSCHKA, 2013).

A nossa defesa é que a Geografia é uma importante forma de conhecimento a respeito do espaço e, nesse contexto, de nós, dos outros e do mundo em que vivemos. Como disciplina escolar desempenha fundamental papel na formação de cidadãos conscientes, reflexivos, críticos e informados do seu mundo, seus condicionantes e 
possibilidades. Contudo, essa disciplina escolar nem sempre esteve voltada à emancipação de seus sujeitos, pois foi também utilizada para inculcar ideologias das classes dirigentes e interesses hegemônicos. Embora não seja o único caso, é marcante no contexto brasileiro a ideologia imposta pela Junta Militar que controlou o país no período entre 1964 a 1985 (GÁUDIO e BRAGA, 2007).

À lógica desse contexto, a escola que se apropria dos princípios do movimento decolonial é responsável por (re)construir, com diversas gerações, a partir dos espaços de exclusão, considerando toda pluralidade de vozes e territórios, uma síntese do conhecimento produzido e sistematizado pela sociedade. Nota-se, ainda, que ela parece estar um passo atrás das renovações no modo de pensar, empreendidas pela academia e outros setores, não por falta de excelentes pesquisadores e professores nas áreas de Educação e Geografia, mas porque a renovação e a incorporação de novas tendências na escola, em termos práticos, sofrem várias resistências.

O respeito à individualidade e liberdade de escolha, por exemplo, ainda é claramente oprimido por preconceitos religiosos e crenças, inclusive por parte dos professores (VAIDERGORN, 2008; JEOLÁS e PAULILO, 2008; TORTATO e CARVALHO, 2010). Nesse sentido, pesquisas na área, a exemplo dos trabalhos de Aquino (1998), Mendonça (2011) e Bezerra e Suess (2015), atestam a existência de um padrão de escola pouco atrativo, onde não se consideram as demandas de formação da contemporaneidade, tampouco o que acontece no cotidiano dos alunos, entre outros aspectos.

No que se refere à Geografia Escolar pode-se afirmar que a fenomenologia, assim como o materialismo histórico dialético, contribui para uma nova forma de pensar o ensino, a aprendizagem e a relação entre ambas, não somente em nível acadêmico, como também em âmbito escolar. Trata-se de um tipo de humanismo e, como tal, influencia no modo de pensar e agir, mas também em uma atitude ética e estética. De modo geral, o humanismo objetiva valorizar o sujeito humano e toda sua amálgama de possibilidades. Sendo assim, nós que desenvolvemos um humanismo em Geografia temos na decolonialidade mais um novo arcabouço filosófico e teórico que nos permite 
reconstruir a nossa leitura de mundo, ressignificar a nossa produção de conhecimentos e transformar o nosso pensar-agir em sala de aula.

Além do currículo oficial, que ainda não incorporou alguns princípios decoloniais e sofre várias resistências para tal, temos em todos os espaços escolares o currículo oculto. Trata-se de um currículo que permeia a subjetividade de todos aqueles que estão envolvidos direta ou indiretamente no processo de ensino-aprendizagem na escola. Ele reflete atitudes e valores, práticas, relações hierárquicas, regras e procedimentos, modos de pensar-agir não explicitamente claros que interferem diretamente no trabalho pedagógico formal. Observa-se que em muitos casos esse currículo pode ir de encontro com aquele projeto de sociedade implicado no currículo oficial ou demandado pelo coletivo e trata-se de um empecilho para o seu desenvolvimento. Pelas raízes e desenvolvimento histórico de nosso país, um dos elementos mais negativos desse currículo ainda é uma sociedade machista, homofóbica, racista e patriarcal que ataca diretamente a construção da cidadania na escola. Outro aspecto que tem forte poder simbólico é a globalização capitalista que acaba minando o cotidiano dos alunos e fortalecendo valores como o consumismo, individualismo, sexismo e etnocentrismo (MOREIRA e CANDAU, 2007).

A interação entre os princípios de currículo, conhecimento e cultura, e a conjuntura que demanda um novo enfrentamento relacionado aos desafios e demandas da diversidade cultural, historicamente relegada a um segundo plano no Brasil, fez com que Moreira e Candau (2007) propusessem orientações para a construção de currículos multiculturamente orientados. Deve-se ressaltar que essa reescrita deve evidenciar a ancoragem social desses conhecimentos, constituir em um elemento de crítica cultural, de diálogo, e de desenvolvimento de pesquisas efetivadas por meio de um trabalho coletivo (MOREIRA e CANDAU, 2007). Trata-se de um currículo que pode contribuir ao processo da valorização da interculturalidade, da unidade na diversidade e da Pedagogia da Tolerância, defendida na seção anterior. De igual modo, poderia contribuir de forma significativa para um novo currículo em Geografia. 


\subsection{Como a decolonialidade pode contribuir para o ensino de Geografia}

Após as importantes reflexões discorridas anteriormente propomos algumas formas para descolonizar a Geografia Escolar na Educação Básica ou pelo menos posições mínimas para iniciar esse processo. Nesse aspecto, identificamos alguns pontos primordiais:

- resgatar e considerar outros autores da Geografia e das ciências humanas que saiam do eixo do Norte Global, levando em conta produções independentes de brasileiros, latino-americanos, africanos e asiáticos;

- identificar o papel que a América exerceu e exerce no mundo, considerando que foi a partir de sua exploração que a Europa, especificamente a Europa Ocidental, se fez; - atribuir mais relevância ao estudo da América nos conteúdos de Geografia e relacioná-la com outras temáticas como Europa, globalização, integração latinoamericana, urbanização, concentração fundiária, história dos afrodescendentes e valorização dos povos indígenas e camponeses;

- desmitificar a Europa como centro do mundo, inclusive nos mapas e representações geográficas e cartográficas;

- considerar no ensino de Geografia o conceito de raça como categoria de dominação para analisar conteúdos como a Geografia do Brasil e a Geopolítica mundial, com destaque a América. Explicar como a categoria raça tem sido utilizada para justificar as razões apresentadas para as conquistas, novas distribuições de espaços, novos mapas. E, ainda, utilizar esse conceito para desconstruir preconceitos e estereótipos;

- $\quad$ analisar e desmitificar como o colonialismo do poder, o colonialismo do ser e o colonialismo do saber prevalecem na mentalidade da população latino-americana e qual é o seu papel para alimentar o sistema-mundo;

- considerar o genocídio/epistemicídio dos povos indígenas, negros e outras minorias políticas como um projeto de poder. Considerá-lo como um conteúdo básico, viabilizando, assim, o resgate e a valorização da multiplicidade cultural; 
- desmitificar a naturalização da pobreza e o desenvolvimento capitalista como única saída à felicidade e melhoria da qualidade de vida das nações. Identificar e propor alternativas "de" desenvolvimento e "ao" desenvolvimento";

- $\quad$ valorizar a história e os saberes de povos subalternizados. Considerar para além das questões de classes, o gênero, a sexualidade, a mulher, o racismo, o negro, o índio e o diferente para uma nova re(leitura) da sociedade e do espaço geográfico;

- trabalhar com noções de gênero e sexualidade, considerando o corpo como patrimônio fundamental e como ferramenta de libertação e vivência de uma nova experiência espacial. Conhecer e se libertar das amarras impostas à corporeidade é um passo importante para conhecer a si mesmo e o mundo, portanto, para melhor conhecer a Geografia;

- levar em conta o processo de exclusão e dominação que envolveu a consolidação do Estado-nação moderno e debater formas alternativas de organizar os territórios, de modo a respeitar os diversos grupos, interesses e diversas culturas desses povos;

- $\quad$ questionar o modelo civilizatório vigente e propor novas possibilidades pautadas na interculturalidade e transculturalidade;

- utilizar a pesquisa como princípio educativo e como ferramenta de efetivação de um novo ensino de Geografia, já que se constitui enquanto forma de identificar problemas e propor soluções, coletivamente justas e sustentáveis;

- $\quad$ propor uma nova análise do espaço geográfico e de seus conceitos (lugar, território, paisagem, região, sociedade e natureza) a partir da perspectiva decolonial (Quadro 1).

A construção de conceitos geográficos vem sendo considerada uma importante ferramenta para o desenvolvimento do pensamento dos alunos (CAVALCANTI, 2012), visto que os mesmos possibilitam uma leitura e releitura do mundo com um viés espacial crítico, reflexivo e humanista.

Assim, é fundamental que o professor domine mais que os conteúdos das diferentes especialidades da área, é necessário que ele tenha um conceito abrangente e profundo da geografia e de suas finalidades formativas (CAVALCANTI, 2012, p. 156). 
O resultado dessas e outras infinidades de propostas somente se justificam se implicar em uma desconstrução e reconstrução da Geografia e de seu ensino na Educação Básica. Isso significa uma nova leitura do espaço geográfico e uma nova postura diante do outro. Portanto, o resultado tem que ir ao encontro de um projeto maior de sociedade, ou melhor, de sociedades, em que o saber outro, o sentir-pensar outro, a organização outra, e toda liberdade de criação humana seja respeitada. Não se trata de forjar uma nova sociedade baseada em velhos modelos de opressão, na qual para alguns serem felizes uma camada seja destruída ou oprimida. O que a decolonialidade propõe é uma liberdade de poder, de ser e de saber, é um resgate da essência humana e aproximação de nossa natureza.

Com base nas questões supracitadas apresentamos a seguir alguns conceitos geográficos na perspectiva decolonial voltados ao ensino de Geografia no âmbito da Educação Básica.

Quadro 1- Conceitos geográficos na perspectiva decolonial voltados ao ensino de Geografia no âmbito da Educação Básica.

\begin{tabular}{|c|c|c|c|}
\hline Conceito & Definição & Contribuição decolonial & Situações didáticas \\
\hline $\begin{array}{l}\text { Espaço } \\
\text { geográfico }\end{array}$ & $\begin{array}{l}\text { - Conjunto indissociável de } \\
\text { sistema de objetos e } \\
\text { sistema de ações. } \\
\text { - Sociedade e natureza. } \\
\text { - Forma-conteúdo. } \\
\text { - Atividades humanas. } \\
\text { - Técnicas e trabalho. } \\
\text { - Diferença/ } \\
\text { heterogeneidade/ } \\
\text { multiplicidade/ } \\
\text { pluralidade. } \\
\text { - Histórico. }\end{array}$ & $\begin{array}{l}\text { - Questiona a visão eurocêntrica de organização do } \\
\text { espaço/tempo. } \\
\text { - Traz à luz sistema de objetos e sistema de ações } \\
\text { menosprezados historicamente. } \\
\text { - Procura superar a dicotomia sociedade e natureza } \\
\text { a partir de uma visão integrada dos elementos } \\
\text { naturais e humanos. } \\
\text { - Propõe mudança radical na forma e no conteúdo } \\
\text { do sistema-mundo atual por meio de um novo } \\
\text { marco civilizatório. } \\
\text { - Busca valorizar atividades humanas que estejam } \\
\text { em harmonia com os elementos naturais; valoriza } \\
\text { atividades dos povos tradicionais, povos indígenas, } \\
\text { negros, mulheres, camponeses, etc. } \\
\text { - Desconstrução de uma perspectiva de um } \\
\text { desenvolvimento tecnológico e organização do } \\
\text { trabalho que não esteja a serviço de um bem } \\
\text { comum. } \\
\text { - Notabiliza vozes historicamente invisíveis. } \\
\text { - Parte da história para denunciar, questionar e } \\
\text { propor mudanças em nosso espaço geográfico. }\end{array}$ & $\begin{array}{l}\text { - Propor um novo ensino de Geografia } \\
\text { a partir da releitura do espaço } \\
\text { geográfico que leve em conta } \\
\text { propostas teóricas alternativas como as } \\
\text { defendidas pelo movimento } \\
\text { decolonial. } \\
\text { - Trabalhar na perspectiva de viabilizar } \\
\text { uma leitura crítica e transformadora do } \\
\text { espaço geográfico e de nossa } \\
\text { sociedade. } \\
\text { - Estudar e denunciar como a } \\
\text { colonialidade do poder, a } \\
\text { colonialidade do ser, a colonialidade } \\
\text { do saber, a ideia de raça e o } \\
\text { eurocentrismo se materializam na } \\
\text { dimensão do espaço. } \\
\text { - Desmitificar e recontar a história do } \\
\text { espaço mundial levando em conta o } \\
\text { papel da América e do processo de } \\
\text { dominação europeia. } \\
\text { - Valorizar as diversas vozes silenciadas } \\
\text { historicamente na produção do } \\
\text { conhecimento geográfico e na } \\
\text { transformação do espaço geográfico. }\end{array}$ \\
\hline
\end{tabular}




\begin{tabular}{|c|c|c|c|}
\hline & & & $\begin{array}{l}\text { - Estudar e propor mudanças espaciais } \\
\text { a partir da interculturalidade crítica. }\end{array}$ \\
\hline Lugar & $\begin{array}{l}\text { - Espaço dotado de } \\
\text { significados para um } \\
\text { indivíduo ou grupo. } \\
\text { - Espaço vivido } \\
\text { (experiência). } \\
\text { - Sentimentos bons e } \\
\text { ruins. } \\
\text { - Histórias e pessoas. } \\
\text { - Encontro das } \\
\text { horizontalidades e } \\
\text { verticalidades. } \\
\text { - Local-global. }\end{array}$ & $\begin{array}{l}\text { - Transformar o imaginário baseado no lugar numa } \\
\text { crítica radical do poder. } \\
\text { - Identificar como a colonialidade produziu e vem } \\
\text { produzindo ausência de lugar nas ex-colônias } \\
\text { europeias. } \\
\text { - O impacto das tecnologias e da globalização no } \\
\text { lugar. } \\
\text { - Ressignificar a história dos lugares, com destaque } \\
\text { a valorização da diversidade e dos sujeitos. } \\
\text { - Permitir que os diversos grupos apropriem e } \\
\text { utilizem sustentavelmente os seus espaços vividos. }\end{array}$ & $\begin{array}{l}\text { - Levar os alunos a identificarem novas } \\
\text { formas de pensar o mundo que surge } \\
\text { no lugar como resposta a um } \\
\text { confronto entre local-global. } \\
\text { - Favorecer a compreensão das } \\
\text { relações entre as dimensões biofísicas, } \\
\text { culturais e econômicas dos lugares. } \\
\text { - Permitir que os alunos compreendam } \\
\text { o mundo e a si mesmo a partir de seu } \\
\text { mundo vivido. } \\
\text { - Relacionar os acontecimentos do } \\
\text { lugar como resistências e aberturas ao } \\
\text { global. } \\
\text { - Valorização da identidade e história } \\
\text { de vida dos alunos para a construção } \\
\text { de conhecimentos escolares. }\end{array}$ \\
\hline Paisagem & $\begin{array}{l}\text { - Tudo aquilo que } \\
\text { conseguimos ver/perceber } \\
\text { no espaço. } \\
\text { - Dimensão da percepção } \\
\text { (sentidos: visão, audição, } \\
\text { olfato, tato e paladar). } \\
\text { - Museu incompleto. } \\
\text { - Elementos naturais e } \\
\text { humanos. } \\
\text { - Conjuntos de formas. } \\
\text { - Marca e matriz. Visão da } \\
\text { configuração territorial. }\end{array}$ & $\begin{array}{l}\text { - Visibilidade para os elementos invisíveis da } \\
\text { paisagem. } \\
\text { - Inserção de grupos marginalizados na produção } \\
\text { das paisagens. } \\
\text { - Desmitificar e evidenciar como a ideia de raça e } \\
\text { dominação se materializa na paisagem. } \\
\text { - Questionamento do patrimônio paisagístico como } \\
\text { um produto da desigualdade e concentração de } \\
\text { poder. } \\
\text { - Reconstrução e apropriação das paisagens a partir } \\
\text { dos espaços de exclusão. }\end{array}$ & $\begin{array}{l}\text { - Levar os alunos a identificarem o que } \\
\text { está por trás da materialização das } \\
\text { paisagens. } \\
\text { - Questionar por que existem } \\
\text { paisagens mais valorizadas e outras } \\
\text { menos para o sistema capitalista. } \\
\text { - Desvendar o processo de } \\
\text { desigualdade social/espacial e o } \\
\text { racismo/machismo/homofobia por } \\
\text { meio das paisagens. } \\
\text { - Relacionar a paisagem vivida com } \\
\text { outras paisagens mundiais e } \\
\text { estabelecer relações. }\end{array}$ \\
\hline Território & \begin{tabular}{|l} 
- Espaço definido e \\
delimitado por e a partir de \\
relações de poder. \\
- Delimitação do Estado \\
(soberania, limites, \\
fronteiras, identidade). \\
- Dominação (político- \\
econômica, poder, \\
conflitos, guerras). \\
- Multidimencional e \\
multiescalar. \\
- Geometrias do poder.
\end{tabular} & $\begin{array}{l}\text { - A perseverança de comunidade e movimentos de } \\
\text { base étnico-territorial envolvem resistência, } \\
\text { oposição, defesa e afirmação. } \\
\text { - Os territórios são espaços-tempos vitais de inter- } \\
\text { relação com o mundo natural. } \\
\text { - A defesa do território sustenta um projeto de vida, } \\
\text { envolve a segurança alimentar, a autonomia dos } \\
\text { povos, defesa da biodiversidade, conhecimentos e } \\
\text { práticas culturais das comunidades. } \\
\text { - O direito ao território se vincula ao direito à } \\
\text { identidade; o direito do exercício de ser; o direito a } \\
\text { uma visão própria de futuro; uma visão própria de } \\
\text { desenvolvimento ecológico, econômico e social; } \\
\text { direito às formas tradicionais de produção e } \\
\text { organização social. }\end{array}$ & $\begin{array}{l}\text { - Procurar entender como o domínio } \\
\text { do território se constitui em um } \\
\text { importante elemento para dominar } \\
\text { uma população e como isso foi } \\
\text { utilizado pelos europeus. } \\
\text { - Construir um entendimento de } \\
\text { território que permita aos diversos } \\
\text { sujeitos envolvidos uma melhor } \\
\text { apropriação dele e um elemento de } \\
\text { luta. } \\
\text { - Procurar valorizar as diversas escalas, } \\
\text { manifestações e culturas que atuam } \\
\text { nos diversos territórios. } \\
\text { - Questionar qual território tem sido } \\
\text { legado aos grupos historicamente } \\
\text { excluídos. } \\
\text { - Procurar entender como as mulheres, } \\
\text { os negros e a população LGBTQ+ } \\
\text { concebem, se apropriam e } \\
\text { transformam os territórios. }\end{array}$ \\
\hline Região & $\begin{array}{l}\text { - Recorte espacial segundo } \\
\text { critérios preestabelecidos. } \\
\text { - Diferenciação de áreas. } \\
\text { - Controle e planejamento } \\
\text { do território. } \\
\text { - Instrumento de análise } \\
\text { (artifício); instrumento de } \\
\text { prática (fato); instrumento }\end{array}$ & $\begin{array}{l}\text { - Questiona se a atual divisão territorial mundial é a } \\
\text { única possível. } \\
\text { - Possibilita pensar outras organizações sociais que } \\
\text { não se limitam ao Estado-nação. } \\
\text { - Denuncia como a imposição de recortes espaciais } \\
\text { tem causado opressão dos povos e de suas } \\
\text { identidades. }\end{array}$ & $\begin{array}{l}\text { - O papel do professor é desconstruir a } \\
\text { perspectiva que naturaliza a divisão do } \\
\text { mundo e a divisão interna dos países } \\
\text { como algo natural. } \\
\text { - Trabalhar em Geografia formas } \\
\text { alternativas de regionalização que não } \\
\text { se limitam às propostas do Estado e da } \\
\text { academia. }\end{array}$ \\
\hline
\end{tabular}




\begin{tabular}{|c|c|c|c|}
\hline & $\begin{array}{l}\text { de intervenção (plano) e a } \\
\text { perspectiva integradora - } \\
\text { teoria e prática (arte-fato). } \\
\text { - Múltiplas dimensões e } \\
\text { escalas. } \\
\text { - Fins didáticos. } \\
\text { - Identidade. }\end{array}$ & $\begin{array}{l}\text { - Transfere o poder de definir os espaços para todos } \\
\text { os integrantes daquele espaço, com destaque aos } \\
\text { grupos excluídos dessa função: povos tradicionais, } \\
\text { índios, negros, mulheres, dentre outros. }\end{array}$ & $\begin{array}{l}\text { - Trabalhar a identidade e } \\
\text { interculturalidade como elementos } \\
\text { integradores da região. } \\
\text { - Se apropriar da região em sua } \\
\text { perspectiva integradora, visando uma } \\
\text { transformação do espaço que leve em } \\
\text { conta os oprimidos de toda ordem. }\end{array}$ \\
\hline Sociedade & \begin{tabular}{|l|} 
- Não é um mero conjunto \\
de indivíduos vivendo \\
juntos em um determinado \\
lugar, mas define-se \\
essencialmente pela \\
existência de uma \\
organização. \\
- Um conjunto de \\
indivíduos, grupos e \\
instituições, cujos \\
relacionamentos são \\
impessoais, formais, \\
utilitários, especializados e, \\
geralmente, baseados em \\
contratos escritos. \\
- A relação sociedade - \\
natureza é materializada \\
pelo trabalho; o resultado é \\
a produção do espaço. \\
\end{tabular} & $\begin{array}{l}\text { - Resgate da importância de grupos historicamente } \\
\text { excluídos e devastados: povos tradicionais, povos } \\
\text { indígenas, negros, mulheres, camponeses, } \\
\text { população LGBTQ+, dentre outros. } \\
\text { - Propõe organizações outras dos grupos sociais, a } \\
\text { exemplo do sistema comunal (propriedade coletiva } \\
\text { dos recursos combinada com a gestão e utilização } \\
\text { privadas), dos quadros comunitários (diversas e } \\
\text { enormemente variadas configurações coletivas } \\
\text { humanas) e do feminismo comunitário (a } \\
\text { comunidade como princípio includente que cuida } \\
\text { da vida; complementaridade homem-mulher...) e } \\
\text { consideração do pluriverso. } \\
\text { - Trata-se de uma reorganização da sociedade; } \\
\text { novas formas de organização política que resista ao } \\
\text { Estado-Capital. } \\
\text { - Defende uma radical devolução do controle sobre } \\
\text { o trabalho/recursos/produtos, o } \\
\text { sexo/recursos/produtos, } \\
\text { a autoridade/instituições/violência, e sobre a } \\
\text { intersubjetividade/conhecimento/comunicação, isto } \\
\text { é, à vida cotidiana das pessoas. } \\
\text { - Luta por uma socialização do poder entre os } \\
\text { diversos povos que ocupam o mesmo território, o } \\
\text { que significa devolver o controle sobre as condições } \\
\text { de sua existência social a essas pessoas. }\end{array}$ & $\begin{array}{l}\text { - Desconstruir os diversos padrões } \\
\text { impostos ao modo de conceber os } \\
\text { homens e mulheres e suas } \\
\text { organizações sociais. } \\
\text { - Trabalhar em uma perspectiva de } \\
\text { ensino de Geografia que, além de } \\
\text { desconstruir preconceitos, seja uma } \\
\text { ferramenta importante para a } \\
\text { valorização da diversidade via } \\
\text { interculturalidade. } \\
\text { - Estudar e denunciar o machismo, } \\
\text { patriarcalismo, sexismo, racismo, } \\
\text { falocentrismo, homofobia, transfobia, } \\
\text { lesbofobia e outras formas de } \\
\text { preconceitos e projetos de poder que } \\
\text { impedem a humanidade do outro. } \\
\text { - Valorizar as diversas organizações } \\
\text { sociais na constituição histórica da } \\
\text { humanidade. } \\
\text { - Reconhecer e valorizar as diversas } \\
\text { vozes que compõem o pluriverso } \\
\text { humano. }\end{array}$ \\
\hline Natureza & \begin{tabular}{|l|} 
- Espaço da espiral: \\
movimento físico, biológico \\
e humano. \\
- Natureza internalista: o \\
ser humano deve se sentir \\
parte da natureza. \\
- Conforme muda o \\
conceito de natureza e o \\
conceito de ser humano, \\
muda a ideia de Geografia. \\
- Cada fração da natureza \\
abriga uma fração da \\
sociedade atual.
\end{tabular} & $\begin{array}{l}\text { - Não considera a separação entre sociedade e } \\
\text { natureza: entidade multidimensional. } \\
\text { - Questiona a estrita separação entre o mundo } \\
\text { biofísico, o humano e o supranatural. } \\
\text { - Busca entender a relação intrínseca entre ser } \\
\text { humano e natureza. } \\
\text { - Valorização do ritmo da natureza como espaço de } \\
\text { manifestações naturais. } \\
\text { - Desenvolve conceitos como Bién vivir, Pacha } \\
\text { Mama e direito da natureza. } \\
\end{array}$ & $\begin{array}{l}\text { - Questionar técnicas europeias para o } \\
\text { tratamento do meio ambiente dos } \\
\text { trópicos e identificar técnicas utilizadas } \\
\text { pelos povos tradicionais do local e } \\
\text { outras técnicas sustentáveis. } \\
\text { - Desconstruir a ideia de reduzir a } \\
\text { natureza simplesmente a um recurso } \\
\text { financeiro. } \\
\text { - Buscar superar uma visão externalista } \\
\text { da natureza - natureza hostil (algo a } \\
\text { ser dominado, controlado) e natureza } \\
\text { virtuosa (entidade harmônica e } \\
\text { bondosa; ser humano, o elemento } \\
\text { desestabilizador). } \\
\text { - Construir a partir do ensino de } \\
\text { Geografia uma visão internalista de } \\
\text { natureza. } \\
\text { - Buscar entender } \\
\text { fenomenologicamente a relação dos } \\
\text { grupos sociais com a natureza, em } \\
\text { especial os grupos tradicionais e } \\
\text { indígenas. }\end{array}$ \\
\hline
\end{tabular}

Fonte: Elaborado pelos autores, 2019. 
A partir dessa proposição ou re(leitura) dos conceitos geográficos à luz da perspectiva decolonial, consideramos que a decolonialidade tem muito a contribuir para um projeto transformador de educação. Em especial, como tratado ao longo desse trabalho, para o ensino de Geografia.

\section{CONSIDERAÇÕES}

A decolonialidade ajuda na desconstrução de muitas verdades nos ensinadas como absolutas e que povoam a nossa subjetividade a serviço de um projeto excludente de sociedade. Assim, apontamentos decoloniais como o papel da América no sistema-mundo, o eurocentrismo, a ideia de raça associada a um projeto de dominação, a constituição do Estado-nação moderno, a crítica ao desenvolvimento e ao modelo civilizatório, a colonialidade do poder, colonialidade do ser, colonialidade do saber, a interculturalidade e a transculturalidade como ferramentas críticas e de transformação, foram consideradas importantes para que o professor repense a sua prática, os conhecimentos construídos e os conteúdos trabalhados em Geografia, favorecendo uma formação voltada à transformação de sentir-pensar-produzir o nosso espaço geográfico.

Como visto não são poucos os desafios para descolonizar a Geografia Escolar, a começar pelo contexto educativo brasileiro, que historicamente, relega uma pequena importância para a educação em matéria de prioridades e investimentos. Como reflexo desse contexto temos a formação de professores que não se mostra suficiente e tende a superprecarização com a implementação de políticas neoliberais após o ano de 1990. O ensino de Geografia somente pode ser analisado levando em conta essas questões e, também, desenvolvimentos particulares da ciência geográfica brasileira e mundial. A colonialidade do saber já foi mais presente no pensar-fazer dos geógrafos brasileiros, contudo, ainda estamos longe de um rompimento significativo com essa lógica.

Nesse aspecto, o que procuramos realizar nesse trabalho foi um esforço de reflexão das contribuições da decolonialidade para a Geografia e propor ações que podem contribuir para o ensino de Geografia. Entre elas cabe destacar a importância 
de realizar novas leituras da realidade a partir dos conceitos geográficos e do pensamento decolonial aplicados a eles. O resultado dessas proposições deve ser a transformação de sentir-pensar-produzir o nosso espaço geográfico, uma mudança que leve em conta as diversas vozes, incluindo as historicamente excluídas, que considere outras formas de organização, de identidades, de discussões, imagens, de saberes e experiências.

Devemos pensar em modelos alternativos "de" e "ao" desenvolvimento que reinventem o nosso modelo civilizatório, valorizando a nossa diversidade, reduzindo as nossas desigualdades e imprimindo um modelo de desenvolvimento sustentável e justo. A educação é a grande ferramenta para dar respostas a como chegar a esse patamar. Mas antes ou concomitante a esse processo ela precisa oferecer respostas concretas à sociedade. Não é acreditando que a escola é uma empresa, que o aluno é o cliente e que o conhecimento é a mercadoria, que chegaremos lá. O grande desafio é incluir nos padrões de vida digna os milhões de indivíduos excluídos e sem condições básicas para se constituírem cidadãos participantes de uma sociedade em permanente mutação. Para isso, nós professores e interessados por uma educação pública de qualidade, justa, crítica, humanista e decolonial, temos que assumir como sujeitos de história, condicionados, mas não determinados, o leme do nosso futuro.

\section{REFERÊNCIAS}

ANJOS, Rafael Sanzio Araújo dos. O Brasil africano: geografia e territorialidade. Brasília: CIGA/CESPE/UnB, 2010.

AQUINO, Julio Groppa. A indisciplina e a escola atual. Rev. Fac. Educ., São Paulo, v. 24, n. 2, p. 181-204, july. 1998.

BALLESTRIN, Luciana. A América latina e o giro decolonial. Revista Brasileira de Ciência Política. n. 11, Brasília, maio-agosto de 2013, p. 89-117.

BERQUE, Augustin. Paisagem-marca, paisagem-matriz: elementos da problemática para uma geografia cultural. In: CORRÊA, Roberto Lobato;

ROZENDAHL, Zeny (orgs.). Geografia Cultural: uma antologia (1). Rio de Janeiro: Eduerj, p. 239-244, 2012. 
BEZERRA, Rafael Gonçalves; SUESS, Rodrigo Capelle. Representações acerca da escola de ensino médio: um estudo com alunos e professores de Formosa-GO. Revista Cadernos de Educação, Pelotas, RS, n. 50, p. 1-15, 2015.

CASTRO-GÓMES, Santiago; GROSFOGUEL, Ramón. El giro decolonial: reflexiones para una diversidad epistémica más allá del capitalismo global. Bogotá: Siglo del Hombre editores; Universidade Central; Instituto de Estudios Socialies Contemporáneos y Pontificia Universidad Javeriana; Instituto Pensar, p. 25-47, 2007.

CAVALCANTI, Lana de Souza. 0 ensino de Geografia na escola. Campinas, SP: Papirus, 2012.

CORONIL, Fernando. Natureza do pós-colonialismo: do eurocentrismo ao globocentrismo. In: LANDER, Edgardo. A colonialidade do saber: eurocentrismo e ciências sociais perspectivas latino-americanas. Buenos Aires: CLACSO, p. 107-130, 2005.

CORRÊA, Roberto Lobato. Hinterlândia, hierarquias e redes. In: CARLOS, Ana Fani Alessandri (org.). Os caminhos da reflexão sobre a cidade e o urbano. São Paulo: Ed. USP, 1994.

CORRÊA, Região e organização espacial. São Paulo: Editora Ática, 2000.

DUSSEL, Enrique. The Invention of the Americas. Nova lorque: Continuum, 1995.

ESCOBAR, Arturo. O lugar da natureza e a natureza do lugar: globalização ou pósdesenvolvimento? In: LANDER, Edgardo. A colonialidade do saber: eurocentrismo e ciências sociais - perspectivas latino-americanas. Buenos Aires: CLACSO, p. 107-130, 2005.

ESCOBAR, Arturo. Sentipensar con la tierra: novas lecturas sobre desarrollo, territorio y diferencia. Medellín: Ediciones UNAULA, 2014.

FREIRE, Paulo. Pedagogia da autonomia: saberes necessários à prática educativa. São Paulo: Paz e Terra, 1996.

FREIRE, Paulo. Pedagogia da Tolerância. Organização, apresentação e notas Ana Maria Araújo Freire. Rio de Janeiro: Paz e Terra, 2013.

FREIRE, Paulo. Pedagogia dos sonhos possíveis. São Paulo: Paz e Terra, 2014.

FREMÓNT, Armand. A região, espaço vivido. Coimbra: Almedina, 1980.

GÁUDIO, Rogata Soares del; BRAGA, Rosalina Batista. A Geografia, a educação e a construção da ideologia nacional. Terra Livre, Presidente Prudente, Ano 23, v. 1, n. 28, p. 177-196, jan./jun. 2007.

GROSFOGUEL, Ramón. A estrutura do conhecimento nas universidades ocidentalizadas: racismo/sexismo epistêmico e os quatro genocídios/epistemicídios do longo século XVI. Revista Sociedade e Estado, v. 31, n. 1, jan./abr. p. 25-49, 2016.

GROSFOGUEL, Ramón. La opción decolonial: desprendimiento y apertura. Um manifiesto y un caso. Tabula Rasa, n. 8, p. 243-282, 2008.

HAESBAERT, Rogério. O mito da desterritorialização: do "fim dos território" à multiterritorialidade. Rio de Janeiro: Bertrand Brasil, 2016. 
HAESBAERT, Rogério. Regional-global: dilemas da região e da regionalização na Geografia Contemporânea. Rio de Janeiro: Bertrand Brasil, 2014.

JAPIASSÚ, Hilton; MARCONDES, Danilo. Dicionário Básico de Filosofia. Rio de Janeiro: Jorge Zahar Editor, 2001.

JEOLÁS, Leila Sollberger; PAULILO, Maria Angela Silveira. Representações sociais da homossexualidade entre professores do ensino público: continuidades e rupturas. Revista Textos e Contextos, Porto Alegre, v. 7, n. 2, p. 266-285, jul./dez. 2008.

LANDER, Edgardo. A colonialidade do saber: eurocentrismo e ciências sociais - perspectivas latino-americanas. Buenos Aires: CLACSO, p. 107-130, 2005.

LIBÂNEO, José Carlos. O dualismo perverso da escola pública brasileira: escola do conhecimento para os ricos, escola do acolhimento social para os pobres. Educação e Pesquisa, São Paulo, v. 38, n. 1, p. 13-28, 2012.

LIBÂNEO, José Carlos; OLIVEIRA, João Ferreira de; TOSCHI, Mirza Seabra. Educação Escolar: políticas, estrutura e organização. São Paulo: Cortez, 2012.

LUCHESI, Marta, MALANGA, Eliana. Diálogos interculturais e identidades nacionais: transculturalidade e transdisciplinaridade. Visão Global, Joaçaba, v. 14, n.1, p. 73-88, jan/jun. 2011.

MAIA, Doralice Sátyro. Natureza, sociedade e trabalho: conceitos para um debate geográfico. Revista Okara, v. 1, n. 1, p. 33-42, 2007.

MALDONADO-TORRES, Nelson. Sobre la colonialidad del ser: contribuciones al desarrollo de un concepto. In: CASTRO-GÓMES, Santiago; GROSFOGUEL, Ramón. El giro decolonial: reflexiones para una diversidad epistémica más allá del capitalismo global. Bogotá: Siglo del Hombre editores; Universidade Central; Instituto de Estudios Socialies Contemporáneos y Pontificia Universidad Javeriana; Instituto Pensar, p. 25-47, 2007.

MARCHERI, Pedro Lima; ÁLVARES, Silvio Carlos. A epistemologia do racismo no Brasil. RIL Brasília, ano 52, n. 208, out. dez. p. 149-166, 2015.

MASSEY, Doreen. Pelo espaço: uma nova política da espacialidade. Rio de Janeiro: Bertrand Brasil, 2008.

MENDONÇA, Sueli Guadalupe de Lima. A crise de sentidos e significados da escola: a contribuição do olhar sociológico. Cader. Cedes, Campinas, SP, v. 31, n. 85, p. 341-357, set./dez. 2011.

MIGNOLO, Walter. El pensamiento decolonial: despredimiento y apertura. In: CASTROGÓMES, Santiago; GROSFOGUEL, Ramón. El giro decolonial: reflexiones para una diversidad epistémica más allá del capitalismo global. Bogotá: Siglo del Hombre editores; Universidade Central; Instituto de Estudios Socialies Contemporáneos y Pontificia Universidad Javeriana; Instituto Pensar, p. 25-47, 2007.

MIGNOLO, Walter. Historias locales/disenos globales: colonialidad, conocimientos subalternos y pensamiento fronterizo. Madrid: Akal, 2003. 
MIGNOLO, Walter. Te geopolitics of knowledge and the colonial difference. Te South Atlantic Quarterly, v. 101, n. 1, p. 57-95, 2002.

MORAIS, Eliana Marta Barbosa de. $\mathbf{O}$ ensino das temáticas físico-naturais na geografia escolar. 2011. Tese (Doutorado em Geografia Humana) - Faculdade de Filosofia, Letras e Ciências Humanas, Universidade de São Paulo, São Paulo, 2011.

MOREIRA, Antônio Flávio Barbosa; CANDAU, Vera Maria. Indagações sobre currículo: currículo, conhecimento e cultura. Brasília: Ministério da Educação, Secretaria de Educação Básica, 2007.

MOREIRA, Ruy. A formação espacial brasileira: contribuição crítica aos fundamentos espaciais da geografia do Brasil. Rio de Janeiro: Consequência, 2014a.

MOREIRA, Ruy. O pensamento geográfico brasileiro: as matrizes brasileiras. São Paulo: Contexto, 2010.

MOREIRA, Ruy. Para onde vai o pensamento geográfico? Por uma epistemologia crítica. São Paulo: Contexto, 2014.

PONTUSCHKA, Nídia Nacib. Políticas Públicas na trajetória do ensino e da formação dos professores: a construção de conhecimentos. In: ALBUQUERQUE, Maria Adailza Martins de; FERREIRA, Joseane Abílio de Sousa (Orgs). Formação, pesquisas e práticas docentes: reformas curriculares em questão. João Pessoa, Ed Mídia, p.433-453, 2013.

QUIJANO, Anibal. Colonialidade do poder, eurocentrismo e América Latina. In: LANDER, Edgardo. A colonialidade do saber: eurocentrismo e ciências sociais - perspectivas latinoamericanas. Buenos Aires: CLACSO, p. 107-130, 2005.

RIBEIRO, Darcy. O Povo Brasileiro: a formação e o sentido do Brasil. Companhia das Letras. São Paulo, 1995.

SANTOS, Milton. A natureza do espaço: Técnica e Tempo. Razão e Emoção. São Paulo: Edusp, 2012.

SAVIANI, Demerval. Histórias das ideias pedagógicas no Brasil. Campinas, SP: Autores Associados, 2008.

SUESS, Rodrigo Capelle. Estudar o lugar para compreender a si mesmo e o mundo: análise de uma experiência pedagógica em Geografia desenvolvida com alunos do $6^{\circ}$ ano do Ensino Fundamental. Revista Brasileira de Educação em Geografia, Campinas, v. 6, n. 12, p. 7498, jul./dez., 2016.

TORTATO, Cíntia de Souza Batista; CARVALHO, Márília Gomes de. Gênero e Sexualidade no cotidiano escolar: sobre as resistências. Fazendo Gênero: Diásporas, diversidades, descolamentos, 9., Florianópolis, 2010. Anais... Florianópolis: UFSC, 2010.

TUAN, Yi-Fu. Espaço e Lugar: a perspectiva da experiência. Tradução de Lívia de Oliveira. Londrina, PR: Eduel, 2013.

TUAN, Yi-Fu. Paisagens do medo. Tradução Lívia de Oliveira. São Paulo: Ed. Unesp, 2005.

TUAN, Yi-Fu. Topofilia: um estudo da percepção, atitudes e valores do meio ambiente. Londrina, PR: Eduel, 2012. 
VAIDERGORN, José. Ensino religioso, uma herança do autoritarismo. Cad. CEDES, Campinas v. 28, n. 76, p. 407-411, Dec. 2008.

WALSH, Catherine. Interculturalidad y (de)colonialidad: Perspectivas críticas y políticas. Visão Global, Joaçaba, v. 15, n. 1-2, p. 61-74, jan./dez. 2012. 